\title{
KESALAHAN BERBAHASA DALAM KARYA TULIS ILMIAH GURU- GURU NONBAHASA INDONESIA SMA KABUPATEN LUWU
}

\author{
Rahmatiah \\ Pendidikan Bahasa Indonesia, Universitas Muhammadiyah Makassar \\ rahmatia@gmail.com
}

\begin{abstract}
Abstrak
Penelitian ini bertujuan mendeskripsikan; (1) Kesalahan penulisan huruf kapital atau huruf besar, (2) Kesalahan penulisan tanda baca, (3) Kesalahan penulisan kosa kata, (4) Kesalahan penulisan penempatan diksi (kata), dan (5) Kesalahan penulisan struktur kalimat (dalam karya tulis ilmiah guru-guru nonbahasa Indonesia SMA Negeri Kabupaten Luwu.Populasi penelitian ini adalah para guru nonbahasa Indonesia SMA Negeri Kabupaten Luwu. Metode penelitian ini adalah metode lapangan yang berbentuk deskriptif kualitatif, dan sampel penelitian ini ditetapkan secara acak (random dari tiga sekolah).

Penelitian ini merupakan penelitian deskriptif kualitatif. Sumber data adalah kalimatkalimat guru yang digunakan dalam karya tulis ilmiah yang mengalami kesalahan penulisan huruf kapital atau huruf besar, penulisan tanda baca, penulisan kosa kata, penempatam diksi (kata), dan penulisan struktur kalimat.

Berdasarkan hasil penelitian bahwa; (1) Kesalahan penulisan huruf kapital atau huruf besar, (2) Kesalahan penulisan tanda baca, , (3) Kesalahan penulisan kosakata, (4) Kesalahan penempatan diksi (kata), (5) Kesalahan penulisan struktur kalimat karya tulis ilmiah para guru nonbahasa Indonesia SMA Negeri Kabupaten Luwu juga masih terdapat kesalahan, sehingga menyebabkan susunan kalimatnya menjadi rancu atau tidak efektif.

Kata Kunci: Kesalahan, Karya tulis ilmiah, Guru Nonbahasa Indonesia.
\end{abstract}

\begin{abstract}
The study aims to describe the singer; (1) Writing Error capital letter OR letters big, (2) Writing Error Punctuation, (3) Writing Error vocabulary, (4) Writing Error Placement diction (words), and (5) Writing Error Grammar (hearts papers scientific teachers of non-linguistic Indonesia SMA Research Luwu.Populasi District teacher is the nonlinguistic singer Indonesia SMA Luwu. Methods Field Methods the singer is a qualitative descriptive shaped, Dan Singer Research samples randomly assigned Operating (random From Three schools).

Singer Research is a qualitative descriptive study. The data source is the sentences teacher who used hearts Scientific papers are experiencing Writing Error big capital letter OR letters, writing punctuation, writing vocabulary, penempatam diction (words), and Writing Grammar.

Based on the findings of that study; (1) Writing Error big letters uppercase OR, (2) Writing Error Punctuation ,, (3) Writing Error vocabulary, (4) Error Placement diction (words), (5) Writing Error Grammar Scientific papers non-linguistic teachers Indonesia SMA Also Luwu There are errors, causing the composition of the sentence ambiguous Become Effective OR NOT.

Keywords: Errors, Scientific papers, non-linguistic teachers Indonesia.
\end{abstract}




\section{PENDAHULUAN}

Guru yang profesionalis adalah guru yang memiliki kemampuan dasar antara lain (1) dasar ilmu yang mampu dijadikan sebagai tolak ukur menyelaraskan perkembangan zaman, (2) penguasaan kiat-kiat profesi berdasarkan olahan riset para praktisi pendidikan, yaitu ilmu pendidikan sebagai ilmu praktisi bukan hanya merupakan konsep teori belaka, (3) pengembangan kemampuan profesionalis yang berkesinambungan, profesi guru merupakan profesi yang dinamis, yaitu Lembaga Penelitian Tindakan Kelas (LPTK) dengan praktek pendidik.

Persyaratan profesionalisme guru, memerlukan paradigma model yang mutakhir untuk melahirkan profil guru bahasa Indonesia yang profesional di abad ke 21; antara lain (1) Memiliki kepribadian yang matang dan berkembang; (2) Penguaan ilmu yang sempurna atau kuat; (3) Keterampilan untuk membangkitkan peserta didik , dan (4) Pengembangan profesi secara berkelanjutan .

Keempat aspek tersebut merupakan satu kesatuan yang utuh, dan tidak dapat dipisahkan disertai usaha lain yang memengaruhi perkembangan profesi guru yang professional. Apakah keempat syarat di atas terpenuhi? Insya Allah akan merubah peran guru yang awalnya pasif akan berubah menjadi guru yang aktif, dan berkemampuan (daya ingat), kreatif, dinamis, dan penuh kegairahan.

Kegiatan menulis merupakan salah satu keterampilan berbahasa yang bersifat produktif artinya kemampuan yang mendorong kegiatan enconding atau kegiatan untuk menghasilkan suatu karya yang dapat dilihat bahkan dinikmati pihak lain yaitu dalam bentuk tulisan. Kegiatan menulis makin mempertajam kepekaan terhadap kesalahan, baik ejaan maupun penempatan diksi atau kata. Hal ini penting karena gagasan dikomunikasikan dengan jelas, tepat, dan teratur sehingga mudah dipahami oleh pembaca.

Pada hakikatnya, kesalahan penggunaan bahasa Indonesia bagi guruguru, utamanya guru nonbahasa Indonesia merupakan fenomena yang wajar. Kesalahan tersebut timbul karena kurangnya pemahaman terhadap kaidahkaidah berbahasa utamanya kaidah menulis, hal ini sering dialami bagi guru yang berlatar belakang pendidikan nonbahasa. Dalam menulis kurang memperhatikan aspek penggunaan huruf kapital dan tanda baca, penggunaan diksi (kata). Pada hal huruf kapital dan tanda baca serta penempatan kata khususnya struktur kalimat sangat menentukan kualitas tulisan.

\section{KAJIAN PUSTAKA}

Harimurti Kridalaksana (2008:14) menyatakan bahwa, "Analisis bahasa (linguistic analysis) istilah umum untuk pelbagai kegiatan yang dilakukan oleh penyelidik bahasa dalam menggarap data yang diperoleh dari penelitian lapangan atau dari pengumpulan teks".

Dapat disimpulkan bahwa analisis kesalahan berbahasa, khususnya bahasa Indonesia adalah suatu teknik yang dipergunakan untuk mengetahui kemampuan pebelajar menggunakan bahasa kedua (bahasa Indonesia) setelah melalui proses belajar dengan cara mengkaji berbagai aspek kesalahan yang tidak sesuai dengan kaidah bahasa Indonesia baku atau penggunaan bahasa Indonesia yang baik dan benar.

Kesalahan berbahasa (kekeliruan berbahasa) berbeda dengan kesilapan berbahasa. Kesalahan dan kesilapan berbahasa dijumpai dalam kegiatan berbahasa, yang kedua-duanya berwujud penyimpangan dari kaidah kebahasaan 
yang berlaku, maupun berupa penyimpangan fonologi, morfologi, atau sintaksis. Lalu mungkin ada yang bertanya tentang perbedaan antara kesalahan dan kesilapan dalam berbahasa, kriteria apa saja yang dapat dipakai untuk menentukan suatu penyimpangan penampilan berbahasa termasuk kesalahan ataukah kesilapan.

Kesalahan berbahasa bersinonim dengan error atau yang oleh Burt dan Kiparsky disebut goat, sedangkan kesilapan bersinonim dengan mistake.Kesalahan berbahasa tampak pada penampilan berbahasa yang bersifat sistematik karena merupakan manifestasi dari sistim bahasa yang sedang dikuasai oleh penutur ( pada tahap tertentu), dan sampai pada tingkat kemampuan atau kompetensi (Burt dan Kiparsky dalam Muh. Amier, 2010:1).

Jadi jelas, bahwa sekalipun antara istilah kesalahan dan kesilapan duaduanya adalah penyimpangan dalam berbahasa, karena tampak sama-sama penutur atau penulis telah menyimpang dari kaidah-kaidah tata bahasa baku namun keduanya tetap terdapat perbedaan yang mendasar yaitu kesalahan terjadi disebabkan faktor kompotensi, artinya pebelajar memang belum memahami sistim linguistik bahasa yang digunakan atau bahasa yang sedang dikuasai atau dipelajari (bahasa kedua).

Sistimatika suatu karya ilmiah sangat perlu disesuaikan untuk menjawab empat pertanyaan berikut: (1) apa yang menjadi masalah, (2) kerangka acuan teoritik apa yang dipakai untuk memecahkan masalah?, (3) bagaimana cara yang telah dilakukan untuk memecahkan masalah itu?, (4) apa yang ditentukan?, serta (5) makna apa yang dapat diambil dari temuan itu? Paparan tentang hal yang menjadi masalah dengan latar belakangnya biasanya dikemas dalam bagian pendahuluan. Paparan tentang kerangka acuan teoritik yang digunakan dalam memecahkan masalah umumnya ditemukan dalam bagian dengan judul Kerangka Teoritis atau Teori dan Landasan Teori, atau Telaah Kepustakaan. Paparan mengenai hal-hal yang dilakukan dikemas dalam bagian yang seringkali diberi judul Metode atau Metodologi atau Prosedur atau Bahan dan Metode. Jawaban terhadap pertanyaan apa yang ditemukan umumnya dikemukakan dalam bagian temuan atau hasil penelitian. Sementara itu paparan tentang makna dari temuan penelitian umunya dikemukakan dalam bahagian pembahasan. Tentu saja sistimatika karya ilmiah ini tidak baku, atau harga mati. Sistimatika karya ilmiah sangat bergantung pada tradisi masyarakat keilmuan dalam bidang terkait jenis karya ilmiah (makalah, laporan penelitian, dan skripsi).

\section{METODE PENELITIAN}

\section{a. Pendekatan dan Jenis Penelitian}

Penelitian ini termasuk penelitian deskriptif, Krik dan Miller (dalam Moleong, 2000:1) menjelaskan bahwa penelitian kualitatif adalah tradisi tertentu dalam ilmu pengetahuann sosial yang secara fundamental bergantung pada pengamatan terhadap manusia dalam kawasannya sendiri dan berhubungan dengan orang-orang tersebut dalam bahasa dan dalam peristilahannya. Selain itu, Bogdan, R. C dan, Biklen, S. K. (1992:36) menyatakan bahwa "Penelitian kualitatif sebagai prosedur penelitian yang menghasilkan data deskriptif berupa kata-kata tertulis atau lisan dan orangorang dan prilaku yang dapat diamati".

\section{b. Lokasi Penelitian}


Penelitian ini dilaksanakan di tiga dapat diketahui melalui tabel berikut:
SMA Kabupaten Luwu, sebagaimana

Tabel 1. Keadaan lokasi penelitian

\begin{tabular}{llll}
\hline N0 & \multicolumn{1}{c}{ Nama sekolah } & \multicolumn{1}{c}{ Tempat } & Keterangan \\
\hline 1. & SMA Negeri 1 Bajo & Kecamatan Bajo & \\
2. & SMA Negeri 1 Larompong & Kecamatan Larompong & \\
3. & SMA Negeri 2 Belopa & Kecamatan Belopa & \\
\hline
\end{tabular}

Sumber: Kepala Badan Kesbangpol dan Linmas Kabupaten Luwu, tgl 10 Juni 2013

\section{c. Data dan Sumber Data}

Data penelitian ini adalah struktur kalimat guru yang digunakan dalam karya tulis ilmiah yang mengalami kesalahan penggunaan huruf kapital, penulisan tanda baca, kosakata dan penempatan diksi (kata) dalam kalimat, serta struktur atau susunan kalimat.

Sumber data dalam penelitian ini adalah karya tulis ilmiah, yang ditulis oleh guru nonbahasa Indonesia, baik berupa skripsi ataupun karya tulis penelitian yang telah digunakan dalam peningkatan karir (kenaikan pangkat/golongan), khusus bagi guruguru nonbahasa Indonesia SMA Kabupaten Luwu yang dihasilkan selama satu tahun terakhir sebanyak tiga buah karya tulis ilmiah sebagai sampel yang ditetapkan secara acak (random dari tiga sekolah).

\section{d. Teknik Pengumpulan Data}

1. Observasi (pengamatan)

Observasi atau pengamatan dilakukan untuk mengamati secara seksama kondisi karya tulis ilmiah guruguru nonbahasa Indonesia SMA Kabupaten Luwu satu tahun terakhir.

2. Dokumentasi

Teknik ini dilakukan dengan mendokumentasikan karya tulis ilmiah guru-guru nonbahasa Indonesia SMA Kabupaten Luwu satu tahun terakhir.

3. Baca
Penulis membaca tiga examplar karya tulis ilmiah guru nonbahasa Indonesia SMA Kabupaten Luwu, yang telah menulis tesis dan skripsi pada jentang strata I dan II dari tiga perguruan tinggi yaitu, STIE YPUP Makassar, FKIP Cokroaminoto Palopo, dan UNM yang telah ditetapkan.

4. Teknik catat

Teknik catat digunakan untuk mencatat data kesalahan berbahasa yang ditemukan dalam karya tulis ilmiah. Data dicatat dalam kartu tanda yang telah disediakan.

\section{e. Teknik Analisis Data}

Penelitian ini berpijak pada konsep analisis kesalahan, yaitu pendekatan yang mengamati kesalahan berbahasa. Teknik analisis yang dipilih adalah teknik deskriptif. Teknik ini mengungkapkan dan memaparkan data sesuai dengan keberadaannya. Teknik tersebut dapat menemukan bentuk kesalahan berbahasa dalam karya tulis ilmiah guru-guru nonbahasa Indonesia SMA Kabupaten Luwu.

Untuk pembahasan dan penafsiran data dilakukan melalui beberapa cara di antaranya adalah tahap pengumpulan data dari sekian jumlah data yang telah terkumpul kemudian diseleksi untuk menentukan data yang dianggap mencerminkan bentuk kesalahan berbahasa dalam karya tulis ilmiah guruguru nonbahasa Indonesia SMA Kabupaten Luwu. 


\section{HASIL PENELITIAN}

Karya tulis ilmiah yang ditulis oleh Abd. Rahman yang berjudul Fungsi Manajemen Sekolah Dikaitkan dengan Keberhasilan Kepemimpinan Kepala Sekolah SMA Negeri 1 Larompong Kecamatan Larompong Kabupaten Luwu, memiliki sebanyak 29 (dua puluh sembilan) kesalahan, dengan perincian sebagai berikut:

1. Kesalahan penulisan huruf kapital sebanyak 7 (tujuh);

2. Kesalahan penulisan tanda baca sebanyak 1 (satu);

3. Kesalahan penulisan kosakata sebanyak 10 (sepuluh);

4. Kesalahan penenpatan diksi sebanyak 10 (sepuluh);

5. Kesalahan penulisan struktur kalimat sebanyak 4 (empat).

Adapun bentuk-bentuk kesalahan tersebut adalah sebagai berikut;

a. Kesalahan huruf kapital atau huruf besar terdiri atas;

Kutipan kesalahan;

Berdasarkan latar belakang dan rumusan masalah diatas, maka tujuan dari penelitian ini adalah : Untuk mengetahui dan menganalisis fungsi manajemen sekolah telah berjalan dengan baik dalam pengelolaan SMA N 1 Larompong Kab. Luwu (hal.6). (P.3)

Perbaikan;

Berdasarkan latar belakang dan rumusan masalah diatas, maka tujuan dari penelitian ini adalah : Untuk mengetahui dan menganalisis fungsi manajemen sekolah telah berjalan dengan baik dalam pengelolaan SMA N 1 Larompong Kab. Luwu.

Penjelasan;

Penulisan kata diatas seharusnya di atas, karena didahului oleh $d i$, yang berperan sebagai kata depan (preposisi) sehingga penulisannya ditulis terpisah dengan kata yang mendahuluinya, kemudian adalah : sebaiknya adalah; karena tulisan tersebut diikuti oleh sejumlah klausa, sementara penulisan tanda baca titik dua (:) ditulis apabila tulisan tersebut diikuti beberapa varian atau unsur-unsur dan penulisannya harus ditulis langsung melekat pada kata yang mendahuluinya, kemudian penulisan SMA N 1 Larompong seharusnya SMA Negeri 1 Larompong.

b. Kesalahan penulisan tanda baca terdiri atas;

Berdasarkan latar belakang dan rumusan masalah diatas, maka tujuan dari penelitian ini adalah : Untuk mengetahui dan menganalisis fungsi manajemen sekolah telah berjalan dengan baik dalam pengelolaan SMA N 1 Larompong Kab. Luwu (hal.6). (P.3)

Perbaikan;

Berdasarkan latar belakang dan rumusan masalah diatas, maka tujuan dari penelitian ini adalah : Untuk mengetahui dan menganalisis fungsi manajemen sekolah telah berjalan dengan baik dalam pengelolaan SMA N 1 Larompong Kab. Luwu.

Penjelasan;

Penulisan kata diatas seharusnya di atas, karena didahului oleh $d i$, yang berperan sebagai kata depan (preposisi) sehingga penulisannya ditulis terpisah dengan kata yang mendahuluinya, kemudian adalah : sebaiknya adalah; karena tulisan tersebut diikuti oleh sejumlah klausa, sementara 
penulisan tanda baca titik dua (:) ditulis apabila tulisan tersebut diikuti beberapa varian atau unsur-unsur dan penulisannya harus ditulis langsung melekat pada kata yang mendahuluinya, kemudian penulisan SMA N 1 Larompong seharusnya SMA Negeri 1 Larompong.

c. Kesalahan penulisan kosakata terdiri atas;

\section{Kutipan kesalahan}

Merupakan karya asli. Seluruh ide yang ada didalam tesis ini, kecuali yang saya nyatakan sebagai kutipan merupakan ide yang saya susun sendiri. Selain itu tidak ada bagian dalam tesis ini yang telah saya gunakan sebelumnya untuk memperoleh gelar atau sertifikat akademik (hal. vi) (P.2)

Perbaikan;

Merupakan karya tulis penulis, seluruh ide yang ada di dalam tesis ini kecuali yang dinyatakan sebagai kutipan, semuanya itu merupakan ide penulis.

Penjelasan;

Kesalahan penulisan pada awal kalimat, terkesan mengandung makna ketaksaan atau ambiguity, artinya tulisan merupakan karya asli, dapat ditafsirkan karya tulis yang asli, dan dapat pula tulisan yang ditulis sendiri oleh penulisnya. Sedangkan penulisan kata didalam seharusnya di dalam, karena penulisan kata tersebut berkaitan langsung dengan penulisan preposisi atau kata depan yang penulisannya ditulis secara terpisah.

d. Kesalahan penulisan penempatan diksi terdiri atas;

Kutipan kesalahan;
Pengkoordinating merupakan suatu aktivitas manajer membawa orang-orang ke dalam suasana kerjasama yang harmonis.

Perbaikan;

Pengoordinasian merupakan suatu aktivitas manajer yang melibatkan orang-orang ke dalam organisasi untuk melakukan kerjasama yang harmonis.

Penjelasan;

Istilah pengkoordinating, berasal dari kata dasar koordinasi, mengalami proses morfologi awalan peng, maka sesuai dengan ketentuan yang berlaku, bahwa apabila meN bertemu dengan kata yang diawali dengan $s, \mathrm{p}, \mathrm{t}$, dan $\mathrm{k}$ maka menjadi luluh, sehingga dengan demikian pengkoordinating seharusnya pengordinasian. Selanjutnya frasa manajer membawa, seharusnya manajer melibatkan orang-orang.

kalimat, melainkan hanya sebagai tambahan argumentasi atau posisinya sebagai objek dalam kalimat. Selanjutnya dalam kaitannya dengan penempatan diksi (dalam bentuk) diganti dengan cara, mengingat bahasa lisan tidak bisa dibentuk, karena informasi lisan sifatnya abstrak. Demikian pula klausa yang terdapat pada akhir paragraf yang tertulis bagi data yang dibutuhkan diganti sebagai pendukung tercapainya tujuan penelitian.

e. Kesalahan penulisan struktur kalimat terdiri atas;

Kutipan kesalahan

Merupakan karya asli. Seluruh ide yang ada didalam tesis ini, kecuali yang saya nyatakan sebagai kutipan merupakan ide 
yang saya susun sendiri. Selain itu tidak ada bagian dalam tesis ini yang telah saya gunakan sebelumnya untuk memperoleh gelar atau sertifikat akademik (hal. vi) (P.2)

Perbaikan;

Merupakan karya tulis penulis, seluruh ide yang ada di dalam tesis ini kecuali yang dinyatakan sebagai kutipan, semuanya itu merupakan ide penulis.

Penjelasan;

Kesalahan penulisan pada awal kalimat, terkesan mengandung makna ketaksaan atau ambiguity, artinya tulisan merupakan karya asli, dapat ditafsirkan karya tulis yang asli, dan dapat pula tulisan yang ditulis sendiri oleh penulisnya. Sedangkan penulisan kata didalam seharusnya di dalam, karena penulisan kata tersebut berkaitan langsung dengan penulisan preposisi atau kata depan yang penulisannya ditulis secara terpisah.

Kesalahan penulisan pada awal kalimat, terkesan mengandung makna ketaksaan atau ambiguity, artinya tulisan merupakan karya asli, dapat ditafsirkan karya tulis yang asli, dan dapat pula tulisan yang ditulis sendiri oleh penulisnya. Sedangkan penulisan kata didalam seharusnya di dalam, karena penulisan kata tersebut berkaitan langsung dengan penulisan preposisi atau kata depan yang penulisannya ditulis secara terpisah.

Karya tulis ilmiah yang ditulis oleh Harnipa yang berjudul "Penerapan Pendekatan PAKEM (Pembelajaran Aktif, Kreatif, Efektif, dan Menyenangkan) untuk Meningkatkan
Keterampilan Berfikir Kreatif Fisika Peserta Didik Kelas VIII3 SMP Negeri 2 Makassar". Terdapat sejumlah 18 (delapan belas ) kesalahan dengan perincian sebagai berikut.

1. Kesalahan penulisan huruf kapital sebanyak 2 (dua);

2. Kesalahan penulisan tanda baca sebanyak 2 (dua);

3. Kesalahan penulisan kosakata sebanyak 2 (dua);

4. Kesalahan penempatan diksi (kata) sebanyak 5 (lima);

5. Kesalahan penulisan struktur kalimat sebanyak 7 (tujuh).

Adapun bentuk-bentuk kesalahan penulisan sebagai berikut:

a. Kesalahan penulisan huruf kapital atau huruf besar adalah;

Kutipan kesalahan ... milik Allah SWT (hal. VI). (P.1)

Perbaikan;

... milik Allah Swt

Penjelasan;

Telah disepakati dan ditetapkan dalam kamus besar bahasa Indonesia bahwa penulisan kata Swt ,huruf awal kata harus kapital . Jadi tulisan yang terdapat pada kutipan tersebut di atas Allah SWT, seharusnya Allah swt.

b. Kesalahan penulisan tanda baca adalah; Kutipan kesalahan;

1. Seberapa besar keterampilan berpikir kreatif fisika peserta didik kelas VIII3 SMP Negeri 2 Makassar tahun ajaran 2011/2012 sebelum diajar dengan pendekatan PAKEM ?

2. Seberapa besar keterampilan berpikir kreatif fisika peserta didik kelas VIII3 SMP Negeri 2 Makassar tahun ajaran 2011/2012 setelah diajar dengan PAKEM ? Perbaikan; 
1. Seberapa besar keterampilan berpikir kreatif fisika peserta didik kelas VIII3 SMP Negeri 2 Makassar tahun ajaran 2011/2012 sebelum diajar dengan pendekatan PAKEM?

2. Seberapa besar keterampilan berpikir kreatif fisika peserta didik kelas VIII3 SMP Negeri 2 Makassar tahun ajaran 2011/2012 setelah diajar dengan PAKEM?

Penjelasan;

Penulisan tanda baca yaitu tanda Tanya (?) ditulis melekat pada kata yang mendahuluinya PAKEM ? seharusnya PAKEM?

c. Kesalahan penulisan kosakata adalah;

Kutipan kesalahan;

Hakekat PAKEM adalah
bagaimana pengajar dapat
mengaktifkan pengetahuan awal
siswa. (hal. 10). (P. 2).

Perbaikan;

Hakikat PAKEM adalah kemampuan pengajar mengaktifkan siswa secara optimal.

Penjelasan;

Penulisan hakekat merupakan kata asing dari bahasa Arab, namun kata tersebut telah dibakukan penulisan ke dalam bahasa Indonesia dari hakekat menjadi hakikat. Selanjutnya frasa adalah bagaimana, seharusnya adalah kemampuan, karena pada prinsipnya tidak diperkenankan para penulis menempatkan kata tanya di tengah kalimat dengan kata lain, kata tanya tidak boleh dijadikan sebagai kata penghubung di tengah kalimat.

d. Kesalahan penempatan diksi (kata) adalah;

Kutipan kesalahan;
Hasil yang diperoleh berdasarkan analisis $\mathrm{N}$-gain menunjukkan untuk tes keterampilan berpikir kreatif mengalami peningkatan dari sebelumnya. Di mana pada hasil tes keterampilan berpikir kreatif sebesar 0,5 ini menunjukkan hasil tes masingmasing berada pada kategori sedang. (hal. 25). (P.2).

Perbaikan;

Hasil yang diperoleh berdasarkan analisis $\mathrm{N}$-gain mengalami peningkatan sebelumnya. Hasil tes keterampilan berpikir kreatif adalah sebanyak 0,5. Ini menunjukkan bahwa hasil tes setiap peserta didik berada pada kategori sedang.

Penjelasan;

Baris ke-2 dalam paragraf tersebut di atas, tertulis peningkatan dari sebelumnya seharusnya peningkatan sebelumnya, dengan pertimbangan bahwa kehadiran dari merupakan pemborosan kata, tanpa kata dari konteks kalimat tetap jelas. Selain itu pula, baris berikutnya tertulis ini menunjukkan hasil tes masingmasing berada ..., seharusnya ini menunjukkan bahwa hasil tes setiap peserta didik berada ....

Konteks dalam kalimat di atas, sifatnya ambiguity atau bermakna ganda sehingga sulit diartikan secara jelas, artinya kemungkinan pertama mengacu pada hasil tes, kemungkinan kedua mengacu pada peserta didik.

e. Kesalahan penulisan struktur kalimat adalah;

Kutipan kesalahan

Subjek dalam penelitian ini adalah peserta didik kelas VIII3 SMP Negeri 2 Makassar Tahun 
ajaran 2011/2012 yang berjumlah 35 peserta didik yang terdiri dari 8 laki-laki dan 27 perempuan. Dimana pada kelas ini paserta didik terpilih karena tidak berdasarkan pada peringkat sehingga dapat dikatakan bahwa keterampilan berpikirnya bervariasi. (hal. 20).(P. 2).

Perbaikan;

Subjek dalam penelitian ini adalah peserta didik kelas VIII3 SMP Negeri 2 Makassar tahun ajaran 2011/2012 yang berjumlah 35 peserta didik, terdiri atas 8 laki-laki; dan 27 perempuan. Di kelas ini ditetapkan sebagai subjek penelitian, karena tidak berdasarkan pada peringkat, sehingga dapat disimpulkan bahwa kemampuan berpikirnya bervariasi.

Penjelasan;

Di awal kalimat ke-2 dalam paragraf ini tertulis Dimana selain cara penulisan tidak tepat seharusnya Di mana, juga kata tersebut tidak sesuai dengan konteks, seharusnya Di kelas, kemudian frasa peserta didik terpilih, seharusnya ditetapkan sebagai subjek penelitian. Hal tersebut didasarkan atas terdapatnya unsur kekaburan dalam kalimat menyebabkan pembaca sangat sulit untuk memaknai.

Karya tulis ilmiah yang ditulis oleh Hasrianto, yang berjudul Efektifitas Pembelajaran Matematika Melalui Penerapan Model "AIR" (Auditory Intellectualy Repetition) Pada siswa SMA Negeri 1 Bajo, memiliki sebanyak 19 (sembilan belas) kesalahan dengan perincian sebagai berikut.

1. Kesalahan penulisan huruf kapital sebanyak 3 (tiga);
2. Kesalahan penulisan tanda baca sebanyak 4(empat);

3. Kesalahan penulisan kosakata sebanyak 5 (lima);

4. Kesalahan penempatan diksi sebanyak 4 (empat);

5. Kesalahan penulisan struktur kalimat sebanyak 3 (tiga).

Adapun bentuk-bentuk kesalahan penulisan sebagai berikut:

a. Kesalahan penulisan huruf kapital adalah;

Kutipan kesalahan;

Puji syukur kehadirat Allah SWT yang telah melimpahkan rahmat, hidayah dan inayahnya sehingga penulis dapat menyelesaikan skripsi ini sesuai dengan waktu yang telah direncanakan. (hal. viii). (P. 1)

Perbaikan;

... kehadirat Allah Swt, yang telah melimpahkan rahmat, hidayah, dan inayah-Nya sehingga, penulis dapat menyelesaikan skripsi ini sesuai dengan waktu yang telah direncanakan.

Penjelasan;

Penulisan penggunaan huruf kapital, tidak sesuai dengan kaidah yang berlaku, misalnya Allah SWT seharusnya Allah Swt, demikian pula penulisan kata ganti nama Allah harus dikapitalkan yaitu terdapat pada baris ke-2 ... hidayah dan inayah-Nya. Kedua bentuk kesalahan tersebut di atas, disebut kesalahan penulisan penggunaan huruf kapital.

b. Kesalahan penulisan huruf capital adalah;

Kutipan kesalahan

Dengan memperhatikan tabel diatas dapat diketahui bahwa instrument penelitian yang diberikan kepada siswa, terdiri 
dari 2 soal mudah, 2 soal sedang dan 1 (satu) soal dikategorikan sukar dengan jumlah soal sebanyak 5 (lima) nomor. Dan telah diuji coba pada siswa diluar sampel. (hal. 25). (P. 2).

Perbaikan;

Memperhatikan tabel di atas dapat diketahu bahwa instrument penelitian yang diberikan kepada siswa terdiri atas 2 (dua) soal mudah, 2 (dua) soal sedang, dan 1 (satu) soal dikategorikan sukar dengan jumlah soal sebanyak 5 (lima) nomor, semua soal tersebut telah diuji coba kepada siswa yang di luar sampel.

Penjelasan;

Kesalahan yang ditemukan dalam paragraf ke-2 di atas, selain kesalahan penempatan diksi (kata), juga terdapat kesalahan lain, di antaranya kesalahan penulisan kata.

Kesalahan kalimat tersebut yaitu Dengan memperhatikan tabel, seharusnya frasa tersebut dihilangkan , diganti dengan frasa berdasarkan tabel, kemudian penulisan kata diatas, seharusnya di atas. Penulisan 2 soal, seharusnya 2 (dua) soal, selanjutnya baris terakhir terdapat sekaligus dua kesalahan yaitu kesalahan tanda baca dan penulisan huruf kapital yaitu nomor. Dan telah seharusnya nomor, dan telah.

c. Kesalahan penulisan kosakata adalah;

Kutipan kesalahan;

Berdasarkan latar belakang diatas hal inilah yang kemudian mendorong penulis .... (hal. 3 ). (P.1).

Perbaikan;
Berdasar latar belakang di atas hal inilah yang kemudian mendorong penulis ....

Penjelasan;

Kesalahan dalam kalimat tersebut di atas, ditemukan dalam penulisan kata yaitu kata depan diatas ditulis serangkai, seharusnya ditulis secara terpisah di atas.

d. Kesalahan penempatan diksi (kata) adalah;

Kutipan kesalahan

Dengan memperhatikan tabel diatas dapat diketahui bahwa instrument penelitian yang diberikan kepada siswa, terdiri dari 2 soal mudah, 2 soal sedang dan 1 (satu) soal dikategorikan sukar dengan jumlah soal sebanyak 5 (lima) nomor. Dan telah diuji coba pada siswa diluar sampel. (hal. 25). (P. 2).

Perbaikan;

Memperhatikan tabel di atas dapat diketahu bahwa instrument penelitian yang diberikan kepada siswa terdiri atas 2 (dua) soal mudah, 2 (dua) soal sedang, dan 1 (satu) soal dikategorikan sukar dengan jumlah soal sebanyak 5 (lima) nomor, semua soal tersebut telah diuji coba kepada siswa yang di luar sampel.

Penjelasan;

Kesalahan yang ditemukan dalam paragraf ke-2 di atas, selain kesalahan penempatan diksi (kata), juga terdapat kesalahan lain, di antaranya kesalahan penulisan kata.

Kesalahan kalimat tersebut yaitu Dengan memperhatikan tabel, seharusnya frasa tersebut dihilangkan , diganti dengan frasa berdasarkan tabel, kemudian penulisan kata diatas, 
seharusnya di atas. Penulisan 2 soal, seharusnya 2 (dua) soal, selanjutnya baris terakhir terdapat sekaligus dua kesalahan yaitu kesalahan tanda baca dan penulisan huruf kapital yaitu nomor. Dan telah seharusnya nomor, dan telah.

e. Kesalahan penulisan struktur kalimat terdiri adalah;

\section{Kutipan kesalahan}

Nampaklah bahwa Bruner sangat menyarankan keaktifan siswa dalam proses belajar secara penuh. Lebih disukai lagi bila proses ini berlangsung di tempat yang lebih khusus dan dilengkapi dengan objek-objek untuk dimanipulasi siswa. (hal. 8). (P. 6).

Perbaikan;

Tampaklah bahwa bruner sangat menyarankan keaktifan siswa dalam proses belajar secara penuh. Lebih disukai lagi bila proses ini berlangsung di tempat yang lebih khusus dan dilengkapi dengan objek-objek untuk diamati langsung oleh siswa.

Penjelasan;

Biasanya kata Nampak digunakan dalam bahasa Indonesia setelah mengalami proses morfologi dari kata dasar tampak, sebab yang diakui sebagai kata dasar baku adalah kata tampak, bukan nampak. Jadi awal kalimat tersebut di atas seharusnya tampaklah.

Kemudian di akhir kalimat muncul kata dimanipulasi , lengkapnya dalam kalimat dilengkapi dengan objek-objek untuk dimanipulasi siswa. Jika diperhatikan makna yang terkandung di dalam kalimat tersebut akan terjadi penafsiran ganda (1) objek-objek tersebut disiasati oleh siswa, (2) objekobjek tersebut dijadikan sumber pembelajaran bagi siswa, (3) objek-objek tersebut diamati langsung oleh siswa.

Jadi berdasarkan ketiga kemungkinan penafsiran kata dimanipulasi, seharusnya diamati langsung oleh siswa.

\section{PEMBAHASAN}

Berdasarkan hasil penelitian yang dilakukan penulis menemukan, bahwa dari tiga examplar karya tulis ilmiah guru-guru nonbahasa Indonesia SMA Negeri Kabupaten Luwu yang dijadikan sampel dalam penelitian ini, secara keseluruhan ditemukan 66 (enam puluh enam) kesalahan dengan rincian sebagai berikut:

1. Kesalahan penulisan huruf kapital 12 (dua belas) kali.

2. Kesalahan penulisan tanda baca 7 (tujuh) kali.

3. Kesalahan penulisan kosakata 17 (tujuh belas) kali.

4. Kesalahan penulisan penempatan diksi (kata) 19 (sembilan belas) kali.

5. Kesalahan penulisan struktur kalimat 14 (empat belas) kali.

Hasil analisis menunjukkan bahwa kesalahan yang paling banyak ditemukan dalam penulisan karya tulis ilmiah para guru nonbahasa Indonesia SMA Negeri Kabupaten Luwu, adalah kesalahan penulisan penempatan diksi dan penulisan kosakata, menyusul kesalahan penulisan struktur kalimat dan huruf kapital, disusul kesalahan penulisan tanda baca.

Kesalahan penulisan para guru nonbahasa Indonesia SMA Negeri Kabupaten 
Luwu, cukup beragam atau bervariasi. Tampak jelas bahwa semua jenis kesalahan penulisan karya tulis ilmiah terdapat kesalahan di semua lini atau jenis-jenis kesalahan. Sebagaimana yang penulis telah gambarkan pada bab II yaitu kesalahan penulisan ejaan berkaitan langsung dengan penulisan huruf kapital dan tanda baca, kesalahan morfologi dan leksikon berkaitan langsung dengan penulisan kosakata dan kesalahan sintaksis berkaitan langsung dengan kesalahan penempatan diksi (kata) dan penulisan struktur kalimat.

\section{Simpulan}

Berdasarkan hasil analisis data dan pembahasan yang telah diuraikan pada bab sebelumnya, maka hasil penelitian ini disimpulkan sebagai berikut:

1. Penulisan huruf kapital atau huruf besar dalam karya tulis ilmiah guruguru nonbahasa Indonesia SMA Negeri Kabupaten Luwu, masih ditemukan kesalahan-kesalahan yang tidak sesuai dengan Ejaan Yang Disempurnakan.

2. Penggunaan tanda baca dalam karya tulis ilmiah para guru nonbahasa Indonesia SMA Negeri Kabupaten Luwu, masih ditemukan kesalahan dalam penempatannya, sehingga tidak sesuai dengan Ejaan Yang Disempurnakan.

3. Kesalahan dalam penulisan kosakata pada karya tulis ilmiah para guru non bahasa Indonesia SMA Negeri Kabupaten Luwu, masih banyak ditemukan, selain tidak sesuai kaidah penulisan, juga tidak relevan dengan bahasa Indonesia baku.

4. Kesalahan penempatan diksi (kata) karya tulis ilmiah para guru nonbahasa Indonesia SMA Negeri Kabupaten Luwu, menempatkan pada tingkat kesalahan terbanyak, menyebabkan susunan kalimatnya menjadi rancu, susah dipahami maknanya.

5. Kesalahan penulisan struktur kalimat karya tulis ilmiah para guru nonbahasa Indonesia SMA Negeri Kabupaten Luwu, juga masih banyak kesalahan sehingga menyebabkan susunan kalimatnya menjadi rancu atau tidak efektif.

\section{DAFTAR PUTAKA}

Rahman, Abd. 2011. Fungsi Manajemen Sekolah Dikaitkan dengan Keberhasilan Kepemimpinan Kepala Sekolah SMA Negeri 1 Larompong Kecamatan Larompong Kabupaten Luwu. Tesis. STIE YPUP Makassar.

Bogdan, R. C. and Biklen, S. K. 1992. Qualotative Research for Education, An Introduction to Theory of Methods. Boston: Allyn and Bacon.

Harnipa. 2012. Penerapaan Pendekatan Pakem (Pembelajaran Aktif, Kreatif, Efektif, dan Menyenangkan) Untuk Meningkatkan Keterampilan Berpikir Kreatif Fisika Peserta Didik Kelas VIII3 SMP Negeri 2 Makassar.Skripsi. Universitas Negeri Makassar.

Hasan, M Z. 1990. Karakteristik Penelitian Kualitatif Pengembangan Penelitian Kualitatif dalam Bidang Bahasa dan Sastra. Malang: Yayasan Asah Asih Asuh.

Hasrianto. 2010. Efektifitas Pembelajaran Matematika Melalui Perencanaan Model "AIR" (Auditory Intellectualy Repetition) Pada Siswa SMA 
Negeri 1 Bajo. Skripsi.

Universitas Cokroaminoto

Palopo.

Keraf, Gorys. 1991. Diksi dan Gaya

Bahasa. (Edisi yang

diperbaharui). Jakarta:

Komposisi. Jakarta: Nusa Indah.

Moleong, Lexy. J. 2000. Metodologi Penelitian Kualitatif. Bandung: Remaja Rosdakarya.

Tarigan, H. G. dan Tarigan, Dj. 1990. Pengajaran Analisis Kesalahan Berbahasa. Bandung: Angkasa.

Tarigan, H. G. dan Lilis. 1996. Analisis Kesalahan Berbahasa. Jakarta: Depdikbud. 